\title{
Evaluation of whole flaxseed and the use of tannin-containing fava beans as an alternative to peas in a co-extruded flaxseed product on ruminal fermentation, selected milk fatty acids, and production in dairy cows
}

\author{
J. Moats, ${ }^{\star} †$ T. Mutsvangwa, ${ }^{*}$ B. Refat, ${ }^{*}$ and D. A. Christensen ${ }^{\star 1}$ \\ *Department of Animal and Poultry Science, University of Saskatchewan, Saskatoon, SK, Canada, S7N 5A8; and \\ †O\&T Farms Ltd., Regina, SK, Canada, S4R 8R7
}

\begin{abstract}
This study evaluated the effects of whole versus extruded flaxseed and the use of tannin-containing fava beans as a replacement for peas in an extruded flaxseed-based supplement on rumen fermentation, selected milk fatty acids, and production in dairy cows. Eight Holstein cows were used in a replicated $4 \times 4$ Latin square consisting of 28-d periods. Cows were fed a control diet (CONT) or 1 of 3 diets that contained a whole flaxseed supplement (FLX), an extruded flaxseed and pea supplement (EXT; linPROR, O\&T Farms Ltd., Regina, SK, Canada), or an extruded flaxseed and tannin-containing fava bean supplement (EXTT). Dry matter intake was less in cows fed FLX, EXT, and EXTT compared with those fed CONT $(P=$ $0.006)$. Milk yield was greater in cows fed EXT $(44.4 \mathrm{~kg} / \mathrm{d})$ compared with those fed FLX $(42.3 \mathrm{~kg} / \mathrm{d} ; P=0.023)$ and tended to be greater in cows fed FLX, EXT, and EXTT (average $43.5 \mathrm{~kg} / \mathrm{d}$ ) compared with those fed CONT (41.9 $\mathrm{kg} / \mathrm{d} ; P=0.073)$. Milk fat percentage was less in cows fed FLX, EXT, and EXTT compared with those fed CONT $(P=0.033)$; however, milk fat yield was unaffected. The C18:3n-3 and cis-9, trans-11 conjugated linoleic acid fatty acids were greater in milk of cows fed EXT compared with those fed FLX $(P=0.001)$. No differences in milk fatty acid composition were observed between EXT and EXTT. These results demonstrate that feeding extruded flaxseed supplements containing peas or tannin-containing fava beans effectively improve milk yield and milk fatty acid profile when compared with whole flaxseed.
\end{abstract}

\footnotetext{
The 3 supplements were manufactured by O\&T Farms, Regina, Saskatchewan, Canada. O\&T Farms manufactures and sells similar extruded products. One author is employed by O\&T Farms. The other authors declare no conflict of interest.

${ }^{1}$ Corresponding author: david.christensen@usask.ca
}

Key words: dairy cow, flaxseed, extrusion, milk fatty acids, tannin-containing fava beans

\section{INTRODUCTION}

Increasing the concentration of total n-3 fatty acids (FA), $\alpha$-linolenic acids (C18:3n-3), and cis-9, trans-11 conjugated linoleic acid (CLA) in bovine milk may benefit consumer health (Lee et al., 2005; Gerber, 2012). Supplementing dairy cow diets with flaxseed products has been suggested as a strategy for improving the concentration of these FA in the milk of dairy cows (Glasser et al., 2008; Petit, 2010; Sterk et al., 2012; Neveu et al., 2013). However, the high concentration of C18:3n-3 in flaxseed (55 g/100 g of total FA; Petit, 2010) has the potential to disrupt ruminal fermentation and cause milk fat depression (NRC, 2001). Additionally, biohydrogenation of C18: 3n-3 by rumen microbial processes limits transfer efficiency of C18:3n-3 into the milk (Sterk et al., 2012). Therefore, protecting the C18:3n-3 from the rumen environment is important for successful application of flaxseed-based feeding programs.

Whole flaxseed has been shown to protect the C18:3n-3 from biohydrogenation (Oba et al., 2009); however, totaltract digestibility of whole oilseeds is poor and limits incorporation of C18:3n-3 into the milk (Petit et al., 2005; Martin et al., 2008). Extrusion of flaxseed has been shown to provide partial protection of C18:3n-3 from biohydrogenation (Kennelly, 1996; Sterk et al., 2012). O\&T Farms Ltd. (Regina, SK, Canada) manufactures an extruded flaxseed-based feed ingredient (linPRO-R) that contains peas, as an oil-absorbent material. In Canada, a $350 \%$ increase in fava bean production between 2013 and 2016 has been reported, with further increases expected (Feyertag, 2017). Increased availability of this crop provides a potential alternative to peas in the linPRO-R product formulation. However, the effects of linPro with peas or fava bean, particularly the FA composition of milk, have not been determined. Therefore, the objective of this study was to 
evaluate the effects of the whole versus extruded flaxseed supplements and the use of tannin-containing fava beans as a replacement for peas in an extruded flaxseed-based supplement on rumen fermentation, selected milk FA, and production in dairy cows.

\section{MATERIALS AND METHODS}

\section{Animal, Experimental Design, and Diets}

Eight multiparous Holstein cows (712.7 $\pm 92.3 \mathrm{~kg}$ of BW; $116.5 \pm 17.5$ DIM at the beginning of the experiment) were used in a replicated $4 \times 4$ Latin square experimental design with 28 -d periods consisting of $20 \mathrm{~d}$ of dietary adaptation and $8 \mathrm{~d}$ of sample and data collection. Four cows in one Latin square were fitted with permanent ruminal cannulas (Bar Diamond Inc., Parma, ID). All experimental procedures were approved by the University of Saskatchewan Animal Care Committee (UCACS Protocol No. 20040048) and were conducted in accordance with the Canadian Council of Animal Care (1993) guidelines. Cows were fed a control diet based on barley silage and alfalfa hay $(48.1 \%$ of DM; CONT), a diet containing a nonextruded flaxseed and pea supplement (FLX), a diet containing a commercially available extruded flaxseed ingredient that uses peas as the main absorbent material (EXT; linPRO-R, O\&T Farms), or a diet containing an extruded flaxseed ingredient that included tannin-containing fava beans as an alternative to peas (EXTT; O\&T Farms). Ingredient and chemical composition of the flaxseed ingredients are described in Table 1 . The ingredient and chemical composition of experimental diets are presented in Table 2, and a detailed list of the diets' FA composition is presented in Table 3. The CONT diet was based on a commercial diet that is commonly used by dairy producers in western Canada. The flaxseed supplements partially replaced the barley-based concentrate at $11.4 \%$ of DM, and the experimental diets containing flaxseed (i.e., the FLX, EXT, and EXTT diets) were formulated to be isoenergetic and isonitrogenous. Experimental diets were mixed into a TMR using a Data Ranger TMR Mixer (American Calan, Northwood, NH). The forage-to-concentrate ratio of the TMR was 50:50 (DM basis), with the forage component being a mixture of barley silage ( $\sim 60 \%$ on a DM basis) and chopped alfalfa hay $(\sim 40 \%)$. The costs of flaxseedsupplemented diets were similar to that of the CONT diet (averaging $2.60 \$ /$ cow per day; Moats, 2016).

\section{Sample Collection and Analyses}

Cows were fed twice daily at 0930 and $1700 \mathrm{~h}$ for ad libitum intake (allowing $\sim 5 \%$ orts). Dry matter intake was recorded daily throughout the experiment. Orts from all 8 cows were collected and weighed daily at $0900 \mathrm{~h}$ over the 8-d collection period for the determination of individual cow feed and FA intake. Orts were pooled per cow per period and stored at $-20^{\circ} \mathrm{C}$ pending chemical analysis. To determine the chemical composition of the experimental diets fed to experimental cows, samples of the individual feed ingredients were collected on d 21 to 23 and stored at $-20^{\circ} \mathrm{C}$ pending chemical analysis. Cows had free access to water.

Cows were milked 3 times daily at 0430, 1230 and 1900 $\mathrm{h}$, and milk weights were recorded using a MM25 milk meter (DeLaval Canada, Peterborough, ON, Canada). Milk samples were collected at each milking over 3 consecutive days (d 26, 27, and 28 of each experimental period) into plastic vials containing 2-bromo-2-nitropropane-1-2-diol as a preservative. Daily milk samples were then pooled proportionally based on milk weights to form a single composite sample of $1,000 \mathrm{~mL}$ for each cow in each period. The composite sample was then subsampled, in duplicate, into vials containing 2-bromo-2-nitropropane-1-2-diol as a preservative and submitted to CanWest DHI Laboratory (Edmonton, AB, Canada) for analysis of milk fat, milk protein, milk lactose, milk urea nitrogen using a midinfrared analyzer (Foss System 4000, Foss Electric, Hillerød, Denmark; AOAC, 1990; method 972.16), and SCC according to the Fossomatic Method (Foss System 4000, Foss Electric). Additional milk samples without preservative were collected in duplicate in $40-\mathrm{mL}$ vials from the composite sample and submitted to Lipid Analytical Services Ltd. (Guelph, ON, Canada) for FA analysis, where fat extraction was conducted according to Bligh and Dyer (1959), with minor modifications as described by Alzahal et al. (2009). Quantification of FA methyl esters (FAME) was conducted using a Varian 3400 CX gas chromatography unit with a Varian 8200 injector (Allegiant Technologies, Mississauga, ON, Canada) using tridecanoin (C13:0) as an internal standard.

To quantify dietary effects on ruminal fermentation characteristics, ruminal contents were collected from the ruminally cannulated cows on d 27 and 28 . A total of 250 $\mathrm{mL}$ of ruminal contents was collected from the cranial-dorsal, ventral-dorsal, caudal-dorsal, and ventral-dorsal sac of the rumen at 0900, 1000, 1100, 1200, 1300, 1600, 1900, and $2200 \mathrm{~h}$ on d 27 and 0100,0400 , and $0700 \mathrm{~h}$ on d 28 to yield a 1,000-mL composite sample. The composite sample was squeezed through 4 layers of cheesecloth, and $\mathrm{pH}$ of the filtrate was measured immediately using a portable pH meter (VWR Symphony SP70C; VWR Canada, Mississauga, ON, Canada). A 10-mL subsample of ruminal fluid was preserved in vials containing $2 \mathrm{~mL}$ of $25 \%$ (wt/ vol) metaphosphoric acid $\left(\mathrm{H}_{2} \mathrm{PO}_{4}\right)$ solution and stored at $-20^{\circ} \mathrm{C}$ pending analysis of short-chain FA (SCFA). Ruminal SCFA samples were separated and quantified by gas chromatography (Agilent 6890, Mississauga, ON, Canada) as described by Khorasani et al. (1996). Another 10-mL subsample of ruminal fluid was preserved in vials containing $2 \mathrm{~mL}$ of $1 \%(\mathrm{wt} / \mathrm{vol})$ sulfuric acid $\left(\mathrm{H}_{2} \mathrm{SO}_{4}\right)$ solution and stored at $-20^{\circ} \mathrm{C}$ pending determination of ammonianitrogen $\left(\mathrm{NH}_{3}-\mathrm{N}\right)$ concentrations according to Broderick and Kang (1980). 
Frozen feed ingredients and orts samples were thawed at ambient temperature and then pooled per cow per period. Feed ingredients were dried in an oven at $60^{\circ} \mathrm{C}$ for $48 \mathrm{~h}$ (AOAC, 1990; method 930.15). Dried feed ingredients and orts were ground through a 1-mm screen (Christy-Norris mill, Christy and Norris Limited, Chelmsford, England) and submitted to Cumberland Valley Analytical Services (Haggerstown, MD) for compositional analysis. Samples were analyzed for DM (AOAC International, 2006; method 930.15), CP (AOAC International, 2000; method 990.03), ADF (AOAC International, 2000; method 973.18), ash (AOAC International, 2000; method 942.05), starch (Hall, 2009), and NDF (Van Soest et al., 1991). The Van Soest et al. (1991) NDF analysis was modified to use Whatman
934.AH glass micro-fiber filters with 1.5 - $\mu \mathrm{m}$ particle retention. Soluble protein was analyzed using the borate-phosphate procedure (Krishnamoorthy et al., 1982). Energy values were calculated according to the Ohio State Summative Equation (Weiss, 1998). Samples of the flaxseed ingredients were submitted to the Lethbridge Research Centre (Lethbridge, AB, Canada) for determination of condensed tannins using the acid-butanol assay (Porter, 1986). The chemical analyses of individual feed ingredients were then used to calculate the chemical composition of experimental diets. Fatty acid analysis of dried feed ingredients and orts was conducted at the Lipid Analytical Services Ltd. as described above. The FA composition of the experimental TMR was determined using the FA com-

Table 1. Ingredient, chemical, and fatty acid composition of flaxseed supplements $(n=4)$

\begin{tabular}{|c|c|c|c|}
\hline \multirow[b]{2}{*}{ Item } & \multicolumn{3}{|c|}{ Flaxseed supplement ${ }^{1}$} \\
\hline & FLX & EXT & EXTT \\
\hline \multicolumn{4}{|l|}{ Ingredient, g/kg of DM } \\
\hline Whole flaxseed & 547 & 547 & 547 \\
\hline Ground field peas & 378 & 378 & - \\
\hline Ground fava beans ${ }^{2}$ & - & - & 378 \\
\hline Dehydrated alfalfa & 69.7 & 69.7 & 69.7 \\
\hline Vitamin $\mathrm{E}^{3}$ & 1.00 & 1.00 & 1.00 \\
\hline Mold inhibitor ${ }^{4}$ & 3.00 & 3.00 & 3.00 \\
\hline Ethoxyquin ${ }^{5}$ & 0.500 & 0.500 & 0.500 \\
\hline \multicolumn{4}{|c|}{ Chemical composition, $\mathrm{g} / \mathrm{kg}$ of DM unless otherwise noted } \\
\hline $\mathrm{DM}, \mathrm{g} / \mathrm{kg}$ & 907 & 912 & 916 \\
\hline Ash & 38.9 & 40.1 & 39.2 \\
\hline $\mathrm{CP}$ & 229 & 236 & 245 \\
\hline Soluble protein, $\mathrm{g} / \mathrm{kg}$ of $\mathrm{CP}$ & 588 & 460 & 460 \\
\hline Starch & 163 & 182 & 186 \\
\hline Sugar & 51.5 & 53.3 & 45.8 \\
\hline Ether extract & 275 & 224 & 225 \\
\hline Condensed tannin; sainfoin extract equivalents & $\mathrm{ND}^{6}$ & ND & 1.17 \\
\hline $\mathrm{NE}_{1},{ }^{7} \mathrm{Mcal} / \mathrm{kg}$ of DM & 2.86 & 2.66 & 2.65 \\
\hline \multicolumn{4}{|l|}{ Fatty acid profile, $\mathrm{g} / 100 \mathrm{~g}$ of $\mathrm{FAME}^{8}$} \\
\hline C18:2n-6 & 26.3 & 21.6 & 18.8 \\
\hline C18:3n-3 & 42.9 & 46.3 & 50.4 \\
\hline Total SFA & 10.7 & 9.95 & 9.64 \\
\hline Total MUFA & 20.1 & 22.0 & 21.1 \\
\hline Total PUFA & 69.2 & 68.1 & 69.3 \\
\hline
\end{tabular}

${ }^{1} \mathrm{FLX}=$ nonextruded flaxseed supplement; EXT = extruded flaxseed and pea supplement (linPRO-R, O\&T Farms Ltd., Regina, SK, Canada); EXTT = extruded flaxseed and tannincontaining fava bean supplement.

${ }^{2}$ Fava bean variety was Malik 9-4.

${ }^{3}$ Microvit (minimum of $500 \mathrm{IU} / \mathrm{g}$; Adisseo, Alpharetta, GA).

${ }^{4}$ No Mold85 (850 g/kg of propionic acid; Agri-Marketing Corp., Mont. St. Hilaire, QB, Canada). ${ }^{5}$ Santoquin (minimum of $910 \mathrm{~g} / \mathrm{kg}$ of ethoxyquin; Novus International Inc., St. Charles, MO). ${ }^{6} \mathrm{ND}=$ not detectable. .

${ }^{7}$ Calculated using the Ohio State Summative Equations (Weiss, 1998).

${ }^{8} \mathrm{FAME}=$ fatty acid methyl esters. 
Table 2. Ingredient composition of experimental diets fed to lactating Holstein cows

\begin{tabular}{|c|c|c|c|c|}
\hline \multirow[b]{2}{*}{ Item } & \multicolumn{4}{|c|}{ Diet $^{1}$} \\
\hline & CONT & FLX & EXT & EXTT \\
\hline \multicolumn{5}{|l|}{ Ingredient, $\mathrm{g} / \mathrm{kg}$ of $\mathrm{DM}$} \\
\hline Barley silage & 282 & 281 & 281 & 281 \\
\hline Alfalfa hay & 200 & 200 & 200 & 200 \\
\hline Ground corn grain & 91.0 & 71.2 & 71.2 & 71.2 \\
\hline Pea grain & 38.0 & 29.9 & 29.9 & 29.9 \\
\hline Ground barley grain & 238.0 & 185.5 & 185.5 & 185.5 \\
\hline Canola meal solvent & 38.6 & 30.2 & 30.2 & 30.2 \\
\hline Soybean meal solvent & 42.6 & 33.3 & 33.3 & 33.3 \\
\hline Corn gluten meal & 9.9 & 7.7 & 7.7 & 8.0 \\
\hline Corn distillers & 16.7 & 13.0 & 13.0 & 13.0 \\
\hline Mineral and vitamin premix ${ }^{2}$ & 12.3 & 9.6 & 9.6 & 9.6 \\
\hline Palmitic acid & 7.2 & 5.6 & 5.6 & 5.6 \\
\hline Molasses cane & 7.5 & 5.9 & 5.9 & 5.9 \\
\hline Biotin $^{3}$ & 0.3 & 0.3 & 0.3 & 0.3 \\
\hline R-choline ${ }^{4}$ & 2.2 & 1.7 & 1.7 & 1.7 \\
\hline $\mathrm{K}-\mathrm{Mg}-\mathrm{S}$ & 0.8 & 0.7 & 0.7 & 0.7 \\
\hline Sodium bicarbonate & 5.3 & 4.1 & 4.1 & 4.1 \\
\hline Limestone & 5.6 & 4.4 & 4.4 & 4.4 \\
\hline Niacin & 0.2 & 0.2 & 0.2 & 0.2 \\
\hline Salt & 2.3 & 1.8 & 1.8 & 1.8 \\
\hline FLX-based products & - & 114 & - & - \\
\hline EXT-based products & - & - & 114 & - \\
\hline EXTT-based products & - & - & - & 114 \\
\hline \multicolumn{5}{|l|}{ Chemical composition } \\
\hline $\mathrm{DM}, \mathrm{g} / \mathrm{kg}$ & 913 & 914 & 917 & 918 \\
\hline $\mathrm{CP}, \mathrm{g} / \mathrm{kg}$ of $\mathrm{DM}$ & 163 & 168 & 168 & 169 \\
\hline NDF, g/kg of DM & 304 & 306 & 308 & 309 \\
\hline Starch, g/kg of DM & 280 & 258 & 259 & 260 \\
\hline Nonfiber carbohydrates, $\mathrm{g} / \mathrm{kg}$ of DM & 416 & 388 & 396 & 391 \\
\hline Ether extract, $\mathrm{g} / \mathrm{kg}$ of DM & 32 & 58 & 57 & 57 \\
\hline Ash, $\mathrm{g} / \mathrm{kg}$ of $\mathrm{DM}$ & 96 & 90 & 90 & 90 \\
\hline $\mathrm{NE}_{1}, \mathrm{Mcal} / \mathrm{kg}$ of DM & 1.55 & 1.68 & 1.66 & 1.66 \\
\hline
\end{tabular}

${ }^{1} \mathrm{CONT}=$ control diet with no flaxseed supplement; FLX = nonextruded flaxseed supplement; EXT = extruded flaxseed and pea supplement (linPRO-R, O\&T Farms Ltd., Regina, SK, Canada); EXTT = extruded flaxseed and tannin-containing fava bean supplement.

${ }^{2}$ Mineral-vitamin premix contained $16 \%$ DM Ca, $7 \%$ DM P, $7 \%$ DM Mg, $2 \%$ DM K, $10 \%$ DM Cl, $1.25 \%$ DM S, $1,507 \mathrm{mg} / \mathrm{kg}$ of Mn, $678 \mathrm{mg} / \mathrm{kg}$ of Cu, $1,005 \mathrm{mg} / \mathrm{kg}$ of Fe, $2,513 \mathrm{mg} / \mathrm{kg}$ of Zn, 80 $\mathrm{mg} / \mathrm{kg}$ of I, $30 \mathrm{mg} / \mathrm{kg}$ of Co, $20 \mathrm{mg} / \mathrm{kg}$ of Se, $251,256 \mathrm{IU} / \mathrm{kg}$ of vitamin A, 80,402 IU $/ \mathrm{kg}$ of vitamin $\mathrm{D}_{3}, 2,010 \mathrm{lU} / \mathrm{kg}$ of vitamin $\mathrm{E}$.

${ }^{3}$ Biotin: $2 \%$ biotin source.

${ }^{4} \mathrm{R}$-choline: $25 \%$ choline source.

positions of the individual feed ingredients. Thereafter, FA intakes were then calculated as (TMR DM offered $\times$ TMR FA content $)-($ orts $\mathrm{DM} \times$ orts FA content)

\section{Statistical Analysis}

Data on production performance and milk FA $(\mathrm{n}=8$ cows) were analyzed as a replicated $4 \times 4$ Latin square design using PROC MIXED (SAS Institute Inc., Cary, NC) according to the following model: $Y_{i j k l}=\mu+S_{i}+P_{j}$ $+C_{k(i)}+T_{l}+E_{i j k l}$, where $Y_{i j k l}$ is the dependent variable, $\mu$ is the overall mean, $S_{i}$ is the fixed effect of square $i, P_{j}$ is the fixed effect of period $j, C_{k(i)}$ is the random effect of cow $k$ within square $i, T_{l}$ is the fixed effect of dietary treatment $l$, and $E_{i j k l}$ is the residual error.

The PROC MIXED procedure of SAS 9.4 was used to analyze the ruminal fermentation data. The final model included period, treatment, sampling time, and treatment $\times$ sampling time interaction as fixed effects; cow as a random effect; and repeated measures for sampling time. Nine covariance structures were tested: autoregressive 1 
(AR [1]), compound symmetry (CS), heterogeneous autoregressive (ARH [1]), unstructured (UN), variance components (VC), Toeplitz (Toep), heterogeneous compound symmetry (CSH), heterogeneous Toeplitz (Toeph), and simple. The covariance structure with the lowest Akaike information criteria values was selected.

Contrast statements were used to compare FLX versus EXT, EXT versus EXTT, and CONT versus the mean of FLX + EXT + EXTT. Significance was declared when $P$ $\leq 0.050$ and trends when $0.050<P \leq 0.100$.

\section{RESULTS AND DISCUSSION}

\section{Experimental Diets}

By design, experimental diets were isonitrogenous and had numerically similar contents of NDF, ADF, and ash (Table 3). Dietary starch content was greater in the CONT $\operatorname{diet}(280 \mathrm{~g} / \mathrm{kg})$ compared with the FLX, EXT, and EXTT diets $($ mean $=259 \mathrm{~g} / \mathrm{kg}$ ), which is primarily reflective of the greater content of corn and barley grain in the CONT diet compared with the other diets (Table 2). The mean ether extract content of the FLX, EXT, and EXTT diets was $55.2 \mathrm{~g} / \mathrm{kg}$, whereas it was $32.1 \mathrm{~g} / \mathrm{kg}$ for the CONT diet, which is reflective of the chemical compositions of the flaxseed supplements. Because the experimental diets containing flaxseed supplements had greater ether extract contents than the CONT diet, their estimated $\mathrm{NE}_{1}$ content $($ mean $=1.67 \mathrm{Mcal} / \mathrm{kg}$ of $\mathrm{DM})$ was greater than that of the CONT diet $(1.56 \mathrm{Mcal} / \mathrm{kg})$. Total PUFA content in the FLX, EXT, and EXTT diets (mean $=475 \mathrm{~g} / \mathrm{kg}$ of FAME) was greater than in the CONT diet $(441 \mathrm{~g} / \mathrm{kg})$. The CONT diet $(143 \mathrm{~g} / \mathrm{kg})$ had a lesser content of C18:3n -3 compared with the FLX, EXT and EXTT diets (mean $=192 \mathrm{~g} / \mathrm{kg}$ ).

The ingredient composition of the flaxseed-based supplements that were used in the present experiment differed only in the presence of field peas or fava beans as an absorbent material (Table 1). Tannin-containing fava beans were chosen as an alternative absorbent material to field peas due to their similar nutrient profiles to field peas and superior production in Canada, and they could be used as a good alternative to soybean or peas in dairy cow rations. The polyphenolic compounds that are present in condensed tannins (CT) have been demonstrated to interfere with the proliferation of rumen microbes such as Bacteroides fibrisolvens and Bacteroides proteoclasticus that are actively involved in rumen biohydrogenation of dietary PUFA, thus inhibiting the process (Vasta et al., 2010). This inhibition of rumen biohydrogenation by CT may result in the accumulation of key biohydrogenation intermediates such as C18:1 trans-11 (Kronberg et al., 2007), which may then be incorporated into milk fat after their absorption at the small intestine. Condensed tannins were not detected in the FLX or EXT supplements, as was anticipated based on the ingredient composition of these flaxseed supplements; however, replacing peas with tannin-containing fava beans in the EXTT supplement resulted in CT levels of $1.17 \mathrm{mg} / \mathrm{g}$ (Table 1). The level of CT that was detected in the EXTT supplement was less than what was detected in the raw product before extrusion (i.e., $6.87 \mathrm{~g} / \mathrm{kg}$; Moats, 2016), which suggests that extrusion processing partially destroys CT. Similar to findings in the present study, Imran et al. (2014) also reported a decrease in CT content of flaxseed meal after extrusion processing. Soluble protein content was less in the EXT and EXTT supplements compared with the FLX supplement, which is in agreement with Alonso et al. (2000), who reported a decrease in pea protein solubility after extrusion processing. The ether extract content of the EXT and EXTT supplements was lesser than that of the FLX supplement, which may be an indication of oil percolation during extrusion processing (Imran et al., 2014). Total MUFA and PUFA concentrations were similar in the FLX, EXT, and EXTT supplements, with C18: 2n-6 and C18:3n-3 being the major FA present. However, C18:3n-3 content was lesser, whereas that of C18:2n-6 was greater in the FLX supplement compared with the EXT and EXTT supplements.

Table 3. Fatty acid composition ( $\mathrm{g} / \mathrm{kg}$ of fatty acid methyl esters) of experimental diets fed to lactating Holstein cows

\begin{tabular}{lcccc} 
& \multicolumn{4}{c}{ Diet $^{1}$} \\
\cline { 2 - 5 } Fatty acid, g/kg of DM & CONT & FLX & EXT & EXTT \\
\hline C14:0 & 9.6 & 8.4 & 8.4 & 8.4 \\
C14:1 cis-9 & 0.3 & 0.3 & 0.3 & 0.3 \\
C15:0 & 1.9 & 1.9 & 1.9 & 1.8 \\
C16:0 & 328 & 290 & 289 & 289 \\
C16:1 cis-9 & 7.1 & 7.2 & 7.2 & 7.2 \\
C18:0 & 52 & 48 & 48 & 48 \\
C18:1 & 132 & 136 & 137 & 138 \\
C18:2n-6 & 297 & 293 & 294 & 287 \\
C18:3n-3 & 143 & 188 & 186 & 192 \\
C20:0 & 4.8 & 4.7 & 4.7 & 4.7 \\
C20:1 cis-11 & 4.8 & 4.8 & 4.8 & 4.8 \\
C22:0 & 7.0 & 7.1 & 6.9 & 7.0 \\
C22:1 & 4.8 & 4.0 & 4.0 & 4.0 \\
C24:0 & 4.9 & 4.9 & 5.0 & 4.9 \\
C24:1 & 1.3 & 1.3 & 1.3 & 1.3 \\
Total SFA & 408 & 365 & 364 & 364 \\
Total MUFA & 150 & 154 & 155 & 156 \\
Total PUFA & 439 & 481 & 480 & 479 \\
\hline
\end{tabular}

${ }^{1} \mathrm{CONT}=$ control diet with no flaxseed supplement; FLX = nonextruded flaxseed supplement; EXT = extruded flaxseed and pea supplement (linPRO-R, O\&T Farms Ltd., Regina, SK, Canada); EXTT = extruded flaxseed and tannin-containing fava bean supplement. 


\section{Feed Intake, Milk Yield, and Milk Composition}

In the present study, DMI for cows fed the FLX, EXT, and EXTT diets was reduced by $7 \%$ compared with cows fed the CONT diet, averaging 24.0 and $25.9 \mathrm{~kg} / \mathrm{d}$, respectively $(P=0.006$; Table 4$)$. A recent meta-analysis involving a total of 78 research papers (based on 84 experiments) with dairy cows showed that dietary supplementation with flaxseed decreases DMI (Leduc et al., 2017). In contrast to our observations, others (Gonthier et al., 2005; Neveu et al., 2013) did not detect differences in DMI in cows fed supplemental flaxseed compared with those fed control diets. In general, dietary supplementation with PUFA-rich fat sources like flaxseed may decrease DMI through a variety of mechanisms. The provision of supplemental fat such that total dietary fat is in excess of 5 to $6 \%$ can decrease DMI via a depression in ruminal fiber digestion (NRC, 2001). The effects of FLX, EXT, EXTT, and CONT on ruminal fiber digestion have been reported, and no negative effects were detected across treatments (Moats, 2016). Previous studies reported a reduction in DMI due to CLA supplementation in nonlactating dairy cows (Urrutia et al., 2017) or in lactating dairy cows (Baumgard et al., 2000; Perfield et al., 2007), without any change in milk yield.

Heat treatments such as micronization and extrusion are widely used to protect the oilseeds from ruminal degradation and to increase their postruminal digestion and, hence, increase feed intake in dairy cows (Schingoethe et al., 1996; Mustafa et al., 2002). There was no effect ( $P=$ 0.242 ) of extrusion of flaxseed on DMI. In agreement with these findings, Gonthier et al. (2005) observed no effect of extrusion of flaxseed on DMI of dairy cows compared with raw flaxseed.

Milk yield tended to increase $(1.6 \mathrm{~kg} / \mathrm{d})$ when cows were fed the FLX, EXT, and EXTT diets compared with the CONT diet $(P=0.073$; Table 4$)$. According to the NRC (2001), milk yield is positively correlated with DMI; in the present study, however, the increase in milk yield with flaxseed supplements occurred when cows fed those diets exhibited a decreased DMI. Based on dietary $\mathrm{NE}_{1}$ contents and DMI, NE intakes were similar in cows fed the CONT diet (40.15 Mcal/d) and diets containing the flaxseed supplements $($ mean $=40.08 \mathrm{Mcal} / \mathrm{d})$. Because $\mathrm{NE}_{1}$ intakes were not different, it is unclear why cows fed diets containing the flaxseed supplements produced more milk when compared with those fed the CONT diet. There are large discrepancies among studies on the effect of flaxseed on milk production (Petit, 2010). An interaction has been found between stage of lactation and the level of flaxseed supplementation, in which as the level of flaxseed increases, the milk yield of dairy cows increases during early lactation, although there was no effect of flaxseed level on milk yield of dairy cows in the mid stage lactation (Onetti and Grummer, 2004; Petit et al., 2009; Petit, 2010). Other studies (Mustafa et al., 2003; Gonthier et al., 2005; Neveu et al., 2013) have reported that flaxseed supplementation

Table 4. Dry matter intake, milk yield, and milk composition of lactating Holstein cows fed experimental diets containing different flaxseed supplements $(n=8)$

\section{Diet $^{1}$}

Diet $^{1}$

Contrast, $P$-value

\begin{tabular}{|c|c|c|c|c|c|c|c|c|}
\hline Item & CONT & FLX & EXT & EXTT & SEM & FLX vs. EXT & EXT vs. EXTT & $\begin{array}{l}\text { CONT vs. FLX } \\
+ \text { EXT + EXTT }\end{array}$ \\
\hline DMI, kg/d & 25.9 & 24.4 & 23.4 & 24.2 & 0.460 & 0.224 & 0.288 & 0.006 \\
\hline $\mathrm{BW}, \mathrm{kg}$ & 722 & 716 & 716 & 717 & 21.5 & 0.990 & 0.897 & 0.391 \\
\hline Milk yield, kg/d & 41.9 & 42.3 & 44.4 & 43.8 & 1.23 & 0.023 & 0.457 & 0.073 \\
\hline $\mathrm{ECM},{ }^{2} \mathrm{~kg} / \mathrm{d}$ & 39.9 & 40.2 & 41.1 & 40.9 & 1.46 & 0.560 & 0.858 & 0.477 \\
\hline Feed efficiency ${ }^{3}$ & 1.61 & 1.68 & 1.71 & 1.74 & 0.067 & 0.299 & 0.537 & 0.084 \\
\hline \multicolumn{9}{|l|}{ Milk composition } \\
\hline Fat, g/kg & 34.9 & 33.9 & 31.5 & 30.4 & 0.134 & 0.138 & 0.491 & 0.033 \\
\hline Protein, g/kg & 31.2 & 30.8 & 30.0 & 30.5 & 0.058 & 0.154 & 0.367 & 0.137 \\
\hline Lactose, $\mathrm{g} / \mathrm{kg}$ & 44.5 & 45.1 & 45.1 & 45.6 & 0.038 & 0.911 & 0.090 & 0.002 \\
\hline \multicolumn{9}{|l|}{ Milk component yield } \\
\hline Fat, kg/d & 1.38 & 1.42 & 1.36 & 1.34 & 0.062 & 0.445 & 0.854 & 0.937 \\
\hline Protein, kg/d & 1.26 & 1.28 & 1.31 & 1.34 & 0.031 & 0.370 & 0.283 & 0.096 \\
\hline Lactose, kg/d & 1.81 & 1.85 & 1.95 & 1.98 & 0.057 & 0.088 & 0.562 & 0.027 \\
\hline Milk urea $\mathrm{N}, \mathrm{mg} / \mathrm{dL}$ & 11.2 & 11.8 & 10.3 & 11.3 & 0.680 & 0.097 & 0.248 & 0.957 \\
\hline
\end{tabular}

${ }^{1}$ CONT = control diet with no flaxseed supplement; FLX = diet including a nonextruded flaxseed and pea supplement; EXT = diet containing an extruded flaxseed and pea supplement (linPRO-R, O\&T Farms Ltd., Regina, SK, Canada); and EXTT = diet containing an extruded flaxseed and tannin-containing fava bean supplement.

${ }^{2} \mathrm{ECM}=$ energy-corrected milk yield calculated according to Orth (1992).

${ }^{3}$ Feed efficiency $=$ ECM/DMI. 
had no effects on milk yield. In the present study, milk yield increased by $2.1 \mathrm{~kg} / \mathrm{d}$ when cows were fed the EXT diet compared with the FLX diet. The greater milk yield that we observed in cows fed the EXT diet was not associated with a greater DMI, which would suggest that alternative mechanisms accounted for the greater milk yield. According to Petit (2010), a review of the literature indicates that physical processing of flaxseed (such as extrusion) typically results in increased milk yields; however, the exact mechanisms responsible for such a response remain unclear. Cows fed the EXTT diet produced similar amounts of milk compared with those fed the EXT diet, suggesting that the replacement of peas with tannin-containing fava beans had no effects on milk production.

Milk fat content decreased $(P=0.03)$ in cows fed the FLX, EXT, and EXTT diets (mean $=31.9 \mathrm{~g} / \mathrm{kg}$ ) compared with those fed the CONT diet $(34.9 \mathrm{~g} / \mathrm{kg})$; however, milk fat yield was unaffected by dietary treatment. Other studies (Martin et al., 2008; Neveu et al., 2013) have also reported a decrease in milk fat content when dairy cow diets are supplemented with flaxseed. This response in milk fat content when flaxseed diets were fed is likely mediated via increased formation of C18:1 trans-10 and CLA trans-10, cis-12 in the rumen, which are intermediates in the biohydrogenation of dietary PUFA. When absorbed from the small intestine, these intermediates are known to have potent inhibitory effects on de novo milk fat synthesis in the mammary gland (Bauman and Griinari 2001; Baumgard et al., 2001; Peterson et al., 2003). In the present study, cows fed the flaxseed supplements had a greater milk fat content of trans-10, cis-12 CLA compared with those fed the CONT diet. In those studies that have reported negative effects of dietary PUFA on milk fat content, milk concentrations of biohydrogenation intermediates such as CLA trans-10, cis-12 have also been elevated (Abdelqader et al., 2009; Reveneau et al., 2012). Although milk fat content was decreased by feeding diets containing flaxseed supplements compared with the CONT diet, milk fat yield was unaffected because cows fed the flaxseed supplements produced more milk.

Milk protein content and yield were unaffected by dietary treatment; however, cows fed the FLX, EXT, and EXTT diets tended to have a greater milk protein yield compared with those fed the CONT diet $(P=0.10)$. This is reflective of the greater milk yield of cows fed the flaxseed supplements. Likewise, Côrtes et al. (2008), Petit et al. (2009), and Neveu et al. (2013) reported no effect of flaxseed supplements on milk protein concentrations. Milk lactose content and yield increased in cows fed the FLX, EXT, and EXTT diets compared with those fed the CONT diet $(P<0.01)$. Milk lactose content tended to be greater $(P=0.08)$ in cows fed the EXTT diet compared with those fed the EXT diet. Also, cows fed the EXT diet tended to have a greater $(P=0.09)$ milk lactose yield compared with those fed the FLX diet. These data agree with a previous work evaluating the effects of flaxseed products on milk composition (Gonthier et al., 2004;
Petit, 2015). Mach et al. (2013) reported an increase in gene expression for liver glucose transporter 2 (GLUT-2) when dairy cattle were fed extruded flaxseed, which may increase liver output of glucose and, subsequently, increase glucose availability for lactogenesis (Petit, 2015). Lactose is the major osmoregulatory substance within the mammary gland (Miglior et al., 2007); therefore, increasing lactose synthesis and transport into the lumen results in increase milk yield due to greater water transport (Rigout et al., 2002). Therefore, the observed differences in lactose concentration and yield in the present study may also be partly responsible for the greater milk yield observed in cows fed the flaxseed-supplemented diets compared with those fed the CONT diet.

\section{FA Intakes and Milk FA Composition}

Overall intakes of crude fat and individual FA are reflective of the differences in dietary composition among treatments, with crude fat intakes being greater in the flaxseed-supplemented diets compared with CONT, averaging 1,373 and $857 \mathrm{~g} / \mathrm{d}$, respectively (Table 5). However, a significant difference in C18:3n-3 intakes was observed between flaxseed-based treatments, with the FLX treatment only consuming an average of $261 \mathrm{~g} / \mathrm{d}$ and the EXT and EXTT treatments consuming an average of $438 \mathrm{~g} / \mathrm{d}$. The differences may be related to feed preferences among supplements; the FLX treatment had visible quantities of whole flaxseed in the orts of the treatment animals. However, further research is needed to validate these observations.

In the present study, feeding dairy cattle diets containing flaxseed altered the FA composition of the milk compared with the CONT diet (Table 6). The de novo FA content (i.e., $<16 \mathrm{C}$ ) of milk is positively correlated with milk fat (Bauman et al., 1970). There was a $14 \%$ reduction in de novo FA $(<16 \mathrm{C})$ as a result of flaxseed supplementation. In agreement with these findings, Mustafa et al. (2003) and Gonthier et al. (2005) reported a reduction in de novo FA when dairy cows were fed flaxseed. However, other studies (Moallem, 2009; Neveu et al., 2013) have not observed any inhibitory effect of flaxseed supplementation on de novo FA synthesis. The extrusion of flaxseed had significantly reduced synthesis of de novo FA relative to raw flaxseed. This reduction could be a consequence of increasing the CLA, which could inhibit the synthesis of de novo FA (Bauman and Griinari, 2001).

There was a large reduction (averaging 23\%) in the medium-chain FA (C12:0 to C16:0) due to flaxseed supplementation relative to CONT. This agrees with previous studies that noted a decrease in the medium FA when oilseed lipid supplementations (protected or not) were fed to dairy cows (Schingoethe et al., 1996; Goodridge et al., 2001).

Milk FA contents of C18:3n-3, and cis-9, trans-11 CLA, were higher $(P<0.001$; Table 6$)$, in FLX, EXT, and EXTT diets compared with in the CONT diet. Total 
Table 5. Crude fat and fatty acid intakes $(\mathrm{g} / \mathrm{d})$ of lactating Holstein cows fed different flaxseed supplements ${ }^{1}$

Diet $^{2}$
Contrast, $P$-value

CONT vs. FLX SEM FLX vs. EXT EXT vs. EXTT + EXT + EXTT

\begin{tabular}{|c|c|c|c|c|c|c|c|c|}
\hline Item, g/d & CONT & FLX & EXT & EXTT & SEM & FLX vs. EXT & EXT vs. EXTT & + EXT + EXTT \\
\hline Crude fat & 857 & 1,490 & 1,310 & 1,320 & 37.8 & $<0.01$ & $<0.01$ & $<0.01$ \\
\hline Total fatty acids & 796 & 1,120 & 1,110 & 1,160 & 52.4 & 0.91 & 0.65 & 0.02 \\
\hline C14:0 & 5.64 & 5.83 & 5.13 & 4.99 & 0.344 & 0.17 & 0.11 & 0.42 \\
\hline C14:1 & 0.145 & 0.099 & 0.114 & 0.118 & 0.012 & 0.42 & 0.32 & 0.05 \\
\hline C15:0 & 0.904 & 0.981 & 0.955 & 0.946 & 0.064 & 0.96 & 0.64 & 0.31 \\
\hline C16:0 & 221 & 229 & 224 & 215 & 11.7 & 0.78 & 0.42 & 0.90 \\
\hline C16:1 & 3.34 & 3.55 & 3.53 & 3.45 & 0.150 & 0.92 & 0.56 & 0.31 \\
\hline C18:0 & 40.5 & 45.1 & 55.5 & 51.5 & 2.68 & 0.04 & 0.15 & 0.02 \\
\hline C18:1 & 151 & 181 & 263 & 239 & 18.4 & 0.03 & 0.08 & 0.02 \\
\hline C18:2n-6 & 272 & 304 & 333 & 365 & 15.8 & 0.04 & 0.24 & 0.02 \\
\hline C18:3n-6 & 0.019 & 0.021 & 0.023 & 0.016 & 0.003 & 0.72 & 0.28 & 0.72 \\
\hline C18:3n-3 & 186 & 261 & 433 & 442 & 45.3 & 0.04 & 0.05 & 0.02 \\
\hline C18:4n-3 & 0.001 & 0.024 & 0.023 & 0.013 & 0.017 & 0.97 & 0.66 & 0.38 \\
\hline C20:0 & 2.72 & 3.04 & 3.34 & 3.45 & 0.154 & 0.11 & 0.22 & 0.03 \\
\hline $\mathrm{C} 20: 1$ & 4.15 & 4.63 & 5.24 & 4.85 & 0.252 & 0.16 & 0.58 & 0.05 \\
\hline$C 20: 2 n-6$ & 0.15 & 0.041 & 0.173 & 0.229 & 0.025 & $<0.01$ & 0.01 & 0.01 \\
\hline$C 20: 3 n-6$ & 0.004 & 0.004 & 0.016 & 0.019 & 0.010 & 0.27 & 0.21 & 0.62 \\
\hline$C 20: 3 n-3$ & 0.001 & 0.071 & 0.148 & 0.240 & 0.054 & 0.07 & 0.37 & 0.05 \\
\hline$C 20: 4 n-3$ & 0.000 & 0.000 & 0.001 & 0.001 & 0.018 & 0.24 & 0.22 & 0.58 \\
\hline$C 20: 5 n-3$ & 0.051 & 0.062 & 0.057 & 0.064 & 0.008 & 0.72 & 0.88 & 0.36 \\
\hline C22:0 & 3.10 & 3.37 & 3.86 & 3.63 & 0.160 & 0.06 & 0.25 & 0.03 \\
\hline $\mathrm{C} 22: 1$ & 3.13 & 3.09 & 2.96 & 2.71 & 0.278 & 0.74 & 0.36 & 0.52 \\
\hline C22:2n-6 & 0.00 & 0.00 & 0.001 & 0.002 & 0.009 & 0.86 & 0.40 & 0.62 \\
\hline$C 22: 4 n-6$ & 0.101 & 0.094 & 0.157 & 0.163 & 0.035 & 0.25 & 0.22 & 0.41 \\
\hline$C 22: 5 n-6$ & 0.001 & 0.001 & 0.001 & 0.001 & 0.000 & 0.55 & 0.29 & 0.67 \\
\hline$C 22: 5 n-3$ & 0.045 & 0.053 & 0.048 & 0.045 & 0.004 & 0.35 & 0.10 & 0.57 \\
\hline C22:6n-3 & 0.039 & 0.045 & 0.054 & 0.051 & 0.009 & 0.44 & 0.61 & 0.30 \\
\hline C24:0 & 1.73 & 1.88 & 2.31 & 2.14 & 0.132 & 0.06 & 0.18 & 0.05 \\
\hline C24:1 & 0.428 & 0.410 & 0.391 & 0.441 & 0.038 & 0.71 & 0.53 & 0.79 \\
\hline Total SFA ${ }^{3}$ & 277 & 276 & 296 & 273 & 16.1 & 0.46 & 0.89 & 0.82 \\
\hline Total MUFA ${ }^{4}$ & 161 & 167 & 229 & 285 & 25.9 & 0.02 & 0.15 & 0.08 \\
\hline Total PUFA ${ }^{5}$ & 457 & 566 & 812 & 765 & 61.3 & 0.04 & 0.08 & 0.02 \\
\hline Total n-3 PUFA ${ }^{6}$ & 158 & 264 & 448 & 428 & 46.1 & 0.04 & 0.05 & 0.01 \\
\hline Total n-6 PUFA ${ }^{7}$ & 265 & 306 & 361 & 332 & 18.0 & 0.08 & 0.34 & 0.03 \\
\hline
\end{tabular}

${ }^{1}$ Values are least squares means obtained from 4 cows.

${ }^{2}$ CONT = control diet with no flaxseed supplement; FLX = diet including a nonextruded flaxseed and pea supplement $(55 \%$ flaxseed, $36 \%$ peas, $8 \%$ alfalfa, $1 \%$ antioxidant); EXT = diet including an extruded flaxseed and pea supplement $(55 \%$ flaxseed, $36 \%$ peas, $8 \%$ alfalfa, $1 \%$ antioxidant; linPRO-R); and EXTT = diet including an extruded flaxseed and hightannin fava bean supplement ( $55 \%$ flaxseed, $36 \%$ fava beans, $8 \%$ alfalfa, $1 \%$ antioxidant). All flaxseed supplements were manufactured by O\&T Farms Ltd. (Regina, SK, Canada).

${ }^{3}$ Total SFA $=\mathrm{C} 10: 0+\mathrm{C} 12: 0+\mathrm{C} 13: 0+\mathrm{C} 14: 0+\mathrm{C} 15: 0+\mathrm{C} 16: 0+\mathrm{C} 17: 0+\mathrm{C} 18: 0+\mathrm{C} 19: 0+\mathrm{C} 20: 0+\mathrm{C} 22: 0+\mathrm{C} 24: 0+\mathrm{C} 26: 0$.

${ }^{4}$ Total MUFA $=\mathrm{C} 14: 1+\mathrm{C} 16: 1+\mathrm{C} 18: 1+\mathrm{C} 20: 1$.

${ }^{5}$ Total PUFA $=$ total $n-3$ PUFA + total n-6 PUFA.

${ }^{6}$ Total n-3 PUFA $=$ C18:3n-3 + C20:3n-3 + C20:5n-3 + C22:3n-3 + C22:5n-3.

${ }^{7}$ Total n-6 PUFA $=C 18: 2 n-6+C 18: 3 n-6+C 20: 2 n-6+C 20: 3 n-6+C 20: 4 n-6+C 22: 4 n-6$.
PUFA were higher in milk of cows fed the FLX, EXT, and EXTT diets (averaging $4.15 \mathrm{~g} / 100 \mathrm{~g}$ of FAME; $P<$ 0.001) compared those fed the CONT diet $(3.55 \mathrm{~g} / 100 \mathrm{~g}$ of FAME). These results agree with previous work that examined changes in milk FA when dairy cattle were fed flaxseed sources (Soita et al., 2003; Gonthier et al., 2005). The cis-9, trans-11 CLA and C18:3n-3 FA are of interest to human health due to their anti-inflammatory and anticarcinogenic properties (Lee et al., 2005; Gerber, 2012). However, the transfer efficiency of C18:3n-3 from feed to 
Table 6. Milk fatty acids in lactating Holstein cows fed experimental diets containing different flaxseed supplements $(n=8)$

$\operatorname{Diet}^{1}$

Contrast, $\boldsymbol{P}$-value

\begin{tabular}{|c|c|c|c|c|c|c|c|c|}
\hline \multirow[b]{2}{*}{ Item } & \multicolumn{4}{|c|}{ Diet $^{1}$} & \multirow[b]{2}{*}{ SEM } & \multicolumn{3}{|c|}{ Contrast, $P$-value } \\
\hline & CONT & FLX & EXT & EXTT & & FLX vs. EXT & EXT vs. EXTT & $\begin{array}{l}\text { CONT vs. F } \\
+E X T+E X\end{array}$ \\
\hline \multicolumn{9}{|l|}{$\begin{array}{l}\text { Fatty acid, } \mathrm{g} / 100 \\
\mathrm{~g} \text { of } \text { FAME }^{2} \text { unless } \\
\text { otherwise noted }\end{array}$} \\
\hline $\mathrm{C} 4: 0$ & 0.58 & 0.64 & 0.61 & 0.59 & 0.028 & 0.369 & 0.533 & 0.238 \\
\hline $\mathrm{C} 6: 0$ & 1.25 & 1.39 & 1.19 & 1.35 & 0.106 & 0.210 & 0.299 & 0.628 \\
\hline C10:0 & 2.47 & 2.36 & 2.02 & 1.95 & 0.150 & 0.027 & 0.155 & 0.045 \\
\hline C12:0 & 3.38 & 3.09 & 2.55 & 2.38 & 0.128 & 0.001 & 0.224 & $<0.001$ \\
\hline C14:0 & 11.8 & 11.3 & 9.49 & 9.68 & 0.250 & $<0.001$ & 0.477 & $<0.001$ \\
\hline C15:0 & 1.18 & 1.07 & 0.90 & 0.92 & 0.057 & 0.001 & 0.611 & $<0.001$ \\
\hline C16:0 & 42.2 & 34.3 & 29.3 & 29.7 & 0.72 & $<0.001$ & 0.521 & $<0.001$ \\
\hline C16:1 & 1.93 & 1.37 & 1.35 & 1.55 & 0.207 & 0.868 & 0.241 & 0.002 \\
\hline C17:0 & 0.49 & 0.46 & 0.42 & 0.41 & 0.009 & $<0.001$ & 0.113 & $<0.001$ \\
\hline C18:0 & 8.0 & 12.1 & 12.2 & 11.6 & 0.87 & 0.876 & 0.349 & $<0.001$ \\
\hline C18:1 & 20.3 & 25.8 & 33.1 & 32.3 & 0.73 & $<0.001$ & 0.303 & $<0.001$ \\
\hline C18:2 n-6 & 2.37 & 2.12 & 2.10 & 2.06 & 0.055 & 0.841 & 0.637 & 0.001 \\
\hline $\mathrm{CLA}^{3}$ & 0.281 & 0.308 & 0.845 & 0.841 & 0.078 & $<0.001$ & 0.962 & $<0.001$ \\
\hline cis- 9, trans-11 & 0.240 & 0.266 & 0.696 & 0.698 & 0.069 & $<0.001$ & 0.986 & $<0.001$ \\
\hline trans -10, cis -12 & 0.027 & 0.030 & 0.100 & 0.094 & 0.009 & $<0.001$ & 0.651 & $<0.001$ \\
\hline C18:3n-6 & 0.039 & 0.068 & 0.092 & 0.129 & 0.013 & 0.189 & 0.053 & 0.001 \\
\hline C18:3n-3 & 0.434 & 0.748 & 0.959 & 0.978 & 0.031 & 0.001 & 0.531 & $<0.001$ \\
\hline C20:0 & 0.160 & 0.166 & 0.283 & 0.251 & 0.050 & 0.101 & 0.646 & 0.197 \\
\hline C20:1 & 0.375 & 0.345 & 0.514 & 0.560 & 0.043 & 0.006 & 0.382 & 0.038 \\
\hline$C 20: 2 n-6$ & 0.006 & 0.009 & 0.007 & 0.006 & 0.003 & 0.632 & 0.837 & 0.600 \\
\hline$C 20: 3 n-6$ & 0.113 & 0.107 & 0.072 & 0.079 & 0.005 & $<0.001$ & 0.293 & $<0.001$ \\
\hline$C 20: 4 n-3$ & 0.013 & 0.040 & 0.046 & 0.050 & 0.005 & 0.116 & 0.218 & $<0.001$ \\
\hline$C 20: 5 n-3$ & 0.056 & 0.071 & 0.074 & 0.072 & 0.004 & 0.546 & 0.695 & $<0.001$ \\
\hline $\mathrm{C} 22: 0$ & 0.0453 & 0.054 & 0.048 & 0.046 & 0.005 & 0.454 & 0.810 & 0.510 \\
\hline $\mathrm{C} 22: 1$ & 0.050 & 0.040 & 0.030 & 0.038 & 0.007 & 0.490 & 0.360 & 0.122 \\
\hline$C 22: 4 n-6$ & 0.000 & 0.007 & 0.001 & 0.003 & 0.003 & 0.159 & 0.680 & 0.314 \\
\hline$C 22: 5 n-3$ & 0.076 & 0.084 & 0.074 & 0.078 & 0.006 & 0.121 & 0.547 & 0.681 \\
\hline $\mathrm{C} 24: 0$ & 0.028 & 0.061 & 0.028 & 0.040 & 0.009 & 0.017 & 0.366 & 0.154 \\
\hline Total SFA 4 & 72.7 & 67.8 & 60.2 & 57.7 & 0.812 & $<0.001$ & 0.628 & $<0.001$ \\
\hline Total MUFA ${ }^{5}$ & 23.7 & 28.5 & 36.0 & 35.4 & 0.785 & $<0.001$ & 0.566 & $<0.001$ \\
\hline Total PUFA ${ }^{6}$ & 3.55 & 3.71 & 4.35 & 4.38 & 0.142 & 0.001 & 0.839 & $<0.001$ \\
\hline Total n-3 PUFA ${ }^{7}$ & 0.579 & 0.940 & 1.15 & 1.18 & 0.035 & 0.001 & 0.518 & $<0.001$ \\
\hline Total n-6 PUFA ${ }^{8}$ & 2.68 & 2.45 & 2.38 & 2.36 & 0.070 & 0.513 & 0.865 & 0.004 \\
\hline \multicolumn{9}{|l|}{ Transfer efficiency } \\
\hline C18:3n-3, g/100 g & 9.02 & 4.35 & 5.58 & 3.63 & 1.583 & 0.407 & 0.597 & 0.036 \\
\hline
\end{tabular}

${ }^{1}$ CONT = control diet with no flaxseed supplement; FLX = diet containing a nonextruded flaxseed and pea supplement; EXT = diet containing an extruded flaxseed and pea supplement (linPRO-R, O\&T Farms Ltd., Regina, SK, Canada); and EXTT = diet containing an extruded flaxseed and tannin-containing fava bean supplement.

${ }^{2} \mathrm{FAME}=$ fatty acid methyl esters.

${ }^{3} \mathrm{CLA}=$ conjugated linoleic acid.

${ }^{4}$ Total SFA $=$ C10:0 + C12:0 + C13:0 + C14:0 + C15:0 + C16:0 + C17:0 + C18:0 + C19:0 + C20:0 + C22:0 + C24:0 + C26:0.

${ }^{5}$ Total MUFA $=$ C14:1 + C16:1 + C18:1 + C20:1.

${ }^{6}$ Total PUFA $=$ total $n-3$ PUFA + total $n-6$ PUFA.

${ }^{7}$ Total n-3 PUFA = C18:3n-3 + C20:5n-3 + C22:5n-3.

${ }^{8}$ Total n-6 PUFA = C18:2n-6 + C18:3n-6 + C20:2n-6 + C20:3n-6 + C20:4n-6 + C22:4n-6. 
milk was less in the flaxseed-based product compared with CON (4.52 vs. $9.01 \mathrm{~g} / 100 \mathrm{~g} ; P=0.04$ ). This would reflect that the part of C18:3n-3 reaching the duodenum of cows fed flaxseed-based products is less available for intestinal absorption or underwent to an extensive ruminal biohydrogenation. In agreement with findings, Gonthier et al. (2005) reported lesser transfer efficiency of C18:3n-3 due to flaxseed supplementation relative to a control diet. Milk FA content of trans-10, cis-12 was greater in cows fed the FLX, EXT, and EXTT diets compared with the CONT $\operatorname{diet}(P<0.001)$. Furthermore, extrusion processing significantly increased milk fat content of trans-10, cis-12 ( $P$ $<0.001$ ). This isomer was produced due to a shift in the biohydrogenation pathways within the rumen that favor production of this isomer and has been linked as an agent for milk fat depression (Bauman and Griinari, 2001; Peterson et al., 2002; Lock et al., 2007). The result in the current study showed that the extrusion process numerically decreased milk fat content in dairy cows by $7 \%$. However, this reduction was not statistically different $(P=0.138)$.

In the present study, an effect on milk FA was observed when comparing FLX- versus EXT-fed cows. Milk content of cis-9, trans-11 CLA and C18:3n-3 increased from 0.266 to $0.696 \mathrm{~g} / 100 \mathrm{~g}$ and 0.745 to $0.980 \mathrm{~g} / 100 \mathrm{~g}$ in cows fed the EXT diet compared with those fed the FLX, respectively. The lower content of healthful FA recovered in the milk of cows fed the FLX diet relative to the EXT diet would reflect differences in dietary C18:3n-3 intake and the transfer efficiency of C18:3n-3. No differences in FA profile were observed between EXT and EXTT treatments. No previous study has been carried out comparing these legumes in an extruded flaxseed-based product on milk FA of dairy cows. The similar milk FA profile in EXT and EXTT could be attributed to the low content of fat in pea and fava bean (averaging $13 \mathrm{~g} / \mathrm{kg}$ of DM; Alibes and Tisserand, 1990).

\section{Ruminal Fermentation}

Dietary effects on ruminal fermentation characteristics are described in Table 7 . There were no sampling time $\times$ treatment interactions for ruminal $\mathrm{pH}$, ruminal concentrations of $\mathrm{NH}_{3}-\mathrm{N}$, and SCFA concentrations. Therefore, only treatment means are presented. Ruminal $\mathrm{pH}$ and ruminal concentrations of individual and total SCFA were unaffected by dietary treatment, except for ruminal acetate concentrations, which were lower in cows fed the EXTT diet compared with those fed the EXT $\operatorname{diet}(P=0.030)$. The decrease in ruminal acetate concentration observed in cows fed EXTT compared with EXT would be attributed to the different chemical composition between fava bean and peas. Fava bean contains a lower sugar concentrations than peas (Table 1). These differences in the carbohydrates profile could result in alterations in ruminal fermentation parameters.

Ruminal concentration of $\mathrm{NH}_{3}-\mathrm{N}$ was lower in cows fed the CONT diet compared with those fed the FLX, EXT, and EXTT diets $(P=0.047)$. Although all diets were isonitrogenous, diets containing the flaxseed supplements had a greater soluble protein content averaging $359 \mathrm{~g} / \mathrm{kg}$ of CP compared with the CONT diet at $316 \mathrm{~g} / \mathrm{kg}$ of CP. These differences in soluble protein may have contributed to increased ruminal $\mathrm{NH}_{3}-\mathrm{N}$ production by increasing the availability of nitrogenous compounds for protease bacteria within the rumen (Bach et al., 2005). Furthermore, the flaxseed treatments contained $11 \%$ less starch than the CONT diet, which could have limited the amount of

Table 7. Ruminal fermentation characteristics of lactating Holstein cows fed different flaxseed supplements $(n=4)$

\begin{tabular}{|c|c|c|c|c|c|c|c|c|}
\hline \multirow[b]{2}{*}{ Item } & \multicolumn{4}{|c|}{ Diet $^{1}$} & \multirow[b]{2}{*}{ SEM } & \multicolumn{3}{|c|}{ Contrast, $P$-value } \\
\hline & CONT & FLX & EXT & EXTT & & FLX vs. EXT & EXT vs. EXTT & $\begin{array}{l}\text { CONT vs. FLX } \\
+ \text { EXT + EXTT }\end{array}$ \\
\hline Rumen pH & 6.07 & 6.03 & 6.00 & 6.03 & 0.0489 & 0.704 & 0.701 & 0.528 \\
\hline \multicolumn{9}{|l|}{ Rumen SCFA,${ }^{2} \mathrm{mmol} / \mathrm{L}$} \\
\hline Acetate & 50.3 & 50.6 & 51.2 & 48.0 & 0.955 & 0.685 & 0.03 & 0.743 \\
\hline Propionate & 18.2 & 18.2 & 19.6 & 20.3 & 0.695 & 0.195 & 0.404 & 0.117 \\
\hline Butyrate & 8.03 & 7.36 & 10.3 & 9.22 & 1.26 & 0.165 & 0.599 & 0.569 \\
\hline Isobutyrate & 0.656 & 0.639 & 0.670 & 0.679 & 0.661 & 0.295 & 0.697 & 0.729 \\
\hline Valerate & 1.12 & 1.09 & 1.08 & 1.04 & 0.198 & 0.280 & 0.810 & 0.128 \\
\hline Isovalerate & 0.982 & 0.935 & 0.982 & 0.926 & 0.0492 & 0.533 & 0.454 & 0.554 \\
\hline Total SCFA & 81.7 & 80.8 & 83.7 & 81.0 & 1.29 & 0.159 & 0.161 & 0.954 \\
\hline Acetate:propionate & 2.76 & 2.76 & 2.69 & 2.61 & 0.171 & 0.753 & 0.637 & 0.598 \\
\hline $\mathrm{NH}_{3}-\mathrm{N}, \mathrm{mg} / \mathrm{dL}$ & 12.0 & 14.2 & 13.1 & 13.7 & 0.846 & 0.362 & 0.476 & 0.047 \\
\hline
\end{tabular}

${ }^{1}$ CONT = control diet with no flaxseed supplement; FLX = diet containing a nonextruded flaxseed and pea supplement; EXT = diet containing an extruded flaxseed and pea supplement (linPRO-R, O\&T Farms Ltd., Regina, SK, Canada); and EXTT = diet containing an extruded flaxseed and tannin-containing fava bean supplement.

${ }^{2}$ SCFA $=$ short-chain fatty acids. 
ruminally fermentable energy that was available for microbial sequestration of ruminal $\mathrm{NH}_{3}-\mathrm{N}$, thus contributing to an increase in free $\mathrm{NH}_{3}-\mathrm{N}$ in the rumen. However, the measurements of ruminal fermentation characteristics in the present study used only 4 dairy cows per dietary treatment. Because of the limited sample size, these data on ruminal fermentation characteristics should be interpreted somewhat cautiously.

\section{IMPLICATIONS}

Current study results suggest that feeding extruded flaxseed products is an effective strategy for improving FA content of C18:3n-3 and cis-9 trans-11 CLA in bovine milk compared with whole flaxseed. Furthermore, extruded flaxseed products showed the greatest improvement in milk production over the control and whole flaxseed while maintaining milk component yields. The lack of response between the 2 extruded flaxseed products suggests fava beans may be a suitable alternative to peas in the commercial linPRO-R product, thereby offering new market potentials for the growing crop market.

\section{ACKNOWLEDGMENTS}

The authors thank Morgan Hobin, Breanna Anderson, and staff of the Rayner Dairy Teaching and Research Facility, University of Saskatchewan, for animal care and technical assistance. This research was supported by the Industrial Research Assistance Program (IRAP; NRC), O \& T Farms Ltd., and SaskMilk.

\section{LITERATURE CITED}

Abdelqader, M. M., A. R. Hippen, K. F. Kalscheur, D. J. Schingoethe, K. Karges, and M. L. Gibson. 2009. Evaluation of corn germ from ethanol production as an alternative fat source in dairy cow diets. J. Dairy Sci. 92:1023-1037. https://doi.org/10.3168/jds.2008-1207.

Alibes, X., and J. L. Tisserand. 1990. Tables of the nutritive value for ruminants of Mediterranean forages and by-products. Options Méditerranéennes: Série B Etudes et recherches; numero 4. CIHEAM 152 p.

Alonso, R., A. Aguirre, and F. Marxo. 2000. Effect of extrusion and traditional processing methods on antinutrients and in vitro digestibility of protein and starch in faba and kidney beans. Food Chem. 68:159-165.

Alzahal, O., M. M. Or-Rashid, S. L. Greenwood, M. S. Douglas, and B. W. McBride. 2009. The effect of dietary fiber level on milk fat concentration and fatty acid profile of cows fed diets containing low levels of polyunsaturated fatty acids. J. Dairy Sci. 92:1108-1116.

AOAC. 1990. Official Methods of Analysis. 15th ed. Assoc. Off. Anal. Chem., Arlington, VA.

AOAC International. 2000. Official Methods of Analysis of AOAC International. 17th ed. AOAC Int., Gaithersburg, MD.

AOAC International. 2006. Official Methods of Analysis of AOAC International. 18th ed. AOAC Int., Gaithersburg, MD.

Bach, A., S. Calsamiglia, and M. D. Stern. 2005. Nitrogen metabolism in the rumen. J. Dairy Sci. 88:E9-E21.
Bauman, D., R. Brown, and C. Davis. 1970. Pathways of fatty acid synthesis and reducing equivalent generation in mammary gland of rat, sow, and cow. Arch. Biochem. Biophys. 140:237-244.

Bauman, D. E., and J. M. Griinari. 2001. Regulation and nutritional manipulation of milk fat: Low-fat milk syndrome. Livest. Prod. Sci. $70: 15-29$

Baumgard, L. H., B. A. Corl, D. A. Dwyer, A. Saebo, and D. E. Bauman. 2000. Identification of the conjugated linoleic acid isomer that inhibits milk fat synthesis. Am. J. Physiol. Regul. Integr. Comp. Physiol. 278:R179-R184.

Baumgard, L. H., J. K. Sangster, and D. E. Bauman. 2001. Milk fat synthesis in dairy cows is progressively reduced by increasing supplemental amounts of trans-10, cis-12 conjugated linoleic acid (CLA). J. Nutr. 131:1764-1769.

Bligh, E. G., and W. J. Dyer. 1959. A rapid method for total lipid extraction and purification. Can. J. Biochem. Physiol. 37:911-917.

Broderick, G. A., and J. H. Kang. 1980. Automated simultaneous determination of ammonia and total amino acids in ruminal fluid and in vitro media. J. Dairy Sci. 63:64-75.

Canadian Council on Animal Care. 1993. Guide to the Care and Use of Experimental Animals. Vol. 1. Canadian Counc. Anim. Care, Ottawa, Ontario, Canada.

Côrtes, C., N. Gagnon, C. Benchaar, D. da Silva, T. D. Santos, and H. V. Petit. 2008. In vitro metabolism of flax lignans by rumen and fecal microflora of dairy cows. J. Appl. Microbiol. 105:1585-1594.

Feyertag, J. 2017. Opportunity for Canadian faba beans: LMC International interim report. CropSphere Conf. presentations. Accessed Apr. 2, 2018. https://www.cropsphere.com/ html/about-cropsphere/2017Speakers-Presentatons/index.cfm.

Gerber, M. 2012. Omega-3 fatty acids and cancers: A systematic update review of epidemiological studies. Br. J. Nutr. 107:S228-S239.

Glasser, F., A. Ferlay, and Y. Chilliard. 2008. Oilseed lipid supplements and fatty acid composition of cow milk: A meta-analysis. J. Dairy Sci. 91:4687-4703.

Gonthier, C., A. F. Mustafa, R. Berthiaume, H. V. Petit, and D. R. Ouellet. 2004. Feeding micronized and extruded flaxseed to dairy cows: Effects on digestion and ruminal biohydrogenation of long-chain fatty acids. Can. J. Anim. Sci. 84:705-711. https://doi.org/10.4141/ A04-003.

Gonthier, C., A. F. Mustafa, D. R. Ouellet, P. Y. Chouinard, R. Berthiaume, and H. V. Petit. 2005. Feeding micronized and extruded flaxseed to dairy cows: Effects on blood parameters and milk fatty acid composition. J. Dairy Sci. 88:748-756.

Goodridge, J., J. R. Ingalls, and G. H. Crow. 2001. Transfer of omega-3 linolenic acid and linoleic acid to milk fat from flaxseed or Linola protected with formaldehyde. Can. J. Anim. Sci. 81:525-532.

Hall, M. B. 2009. Determination of starch, including maltooligosaccharides, in animal feeds: Comparison of methods and a method recommended for AOAC collaborative study. J. AOAC Int. 92:42-49.

Imran, M., F. M. Anjum, M. S. Butt, and M. A. Sheikh. 2014. Influence of extrusion processing on tannin reduction and oil loss in flaxseed (Linum usitatissimum L.) meal. J. Food Process. Preserv. 38:622-629.

Kennelly, J. J. 1996. The fatty acid composition of milk fat as influenced by feeding oilseeds. Anim. Feed Sci. Technol. 60:137-152.

Khorasani, G. R., E. K. Okine, and J. J. Kennelly. 1996. Forage source alters nutrient supply to the intestine without influencing milk yield. J. Dairy Sci. 79:862-872. 
Krishnamoorthy, U., T. V. Muscato, C. J. Sniffen, and P. J. Van Soest. 1982. Nitrogen fractions in selected feedstuffs. J. Dairy Sci. $65: 217-225$.

Kronberg, S. L., E. J. Scholljegerdes, G. Barcelo-Coblijn, and E. J. Murphy. 2007. Flaxseed treatments to reduce biohydrogenation of alpha-linolenic acid by rumen microbes in cattle. Lipids 42:1105-1111.

Leduc, M., M.-P. Létourneau-Montminy, R. Gervais, and P. Y. Chouinard. 2017. Effect of dietary flax seed and oil on milk yield, gross composition, and fatty acid profile in dairy cows: A meta-analysis and meta-regression. J. Dairy Sci. 100:8906-8927. https://doi.org/10 $.3168 /$ jds.2017-12637.

Lee, K. W., H. J. Lee, H. Y. Cho, and Y. J. Kim. 2005. Role of the conjugated linoleic acid in the prevention of cancer. Crit. Rev. Food Sci. Nutr. 45:135-144.

Lock, A. L., C. Tyburczy, D. A. Dwyer, K. J. Harvatine, F. Destaillats, Z. Mouloungui, L. Candy, and D. E. Bauman. 2007. Trans-10 octadecenoic acid does not reduce milk fat synthesis in dairy cows. J. Nutr. 137:71-76.

Mach, N., R. L. G. Zom, H. C. A. Widjaja, P. G. van Wikselaar, R. E. Weurding, M. E. Goselink, J. van Baal, M. A. Smits, and A. M. van Vuuren. 2013. Dietary effects of linseed on fatty acid composition of milk and on liver, adipose and mammary gland metabolism of periparturient dairy cows. J. Anim. Physiol. Anim. Nutr. (Berl.) 97:89-104. https://doi.org/10.1111/jpn.12042.

Martin, C., J. Rouel, J. P. Jouany, M. Doreau, and Y. Chilliard. 2008. Methane output and diet digestibility in response to feeding dairy cows crude linseed, extruded linseed, or linseed oil. J. Anim. Sci. 86:2642-2650.

Miglior, F., A. Sewalem, J. Jamrozik, J. Bohmanova, D. M. Lefebvre, and R. K. Moore. 2007. Genetic analysis of milk urea nitrogen and lactose and their relationships with other production traits in Canadian Holstein cattle. J. Dairy Sci. 90:2468-2479.

Moallem, U. 2009. The effects of extruded flaxseed supplementation to high yielding dairy cows on milk production and milk fatty acid composition. Anim. Feed Sci. Technol. 152:232-242.

Moats, J. 2016. Effects of extruded flaxseed and condensed tannins on rumen fermentation, omasal flow of nutrients, milk composition and milk fatty acid profile in dairy cattle. MSc Thesis. Univ. Saskatchewan, Canada.

Mustafa, A., P. Chouinard, and D. Christensen. 2003. Effects of feeding micronised flaxseed on yield and composition of milk from Holstein cows. J. Sci. Food Agric. 83:920-926. https://doi.org/10.1002/ jsfa. 1430 .

Mustafa, A. F., J. J. McKinnon, D. A. Christensen, and T. He. 2002. Effects of micronization of flaxseed on nutrient disappearance in the gastrointestinal tract of steers. Anim. Feed Sci. Technol. 95:123-132.

Neveu, C., B. Baurhoo, and A. Mustafa. 2013. Effect of feeding extruded flaxseed with different forage: Concentrate ratios on the performance of dairy cows. J. Dairy Sci. 96:3886-3894.

NRC. 2001. Nutrient Requirements of Dairy Cows. 7th revised. ed. Natl. Acad. Press, Washington, DC.

Oba, M., G. Thangavelu, M. Dehghan-banadaky, and D. J. Ambrose. 2009. Unprocessed whole flaxseed is as effective as dry-rolled at increasing linolenic acid concentration in milk of dairy cows. Livest. Sci. 122:73-76.

Onetti, S. G., and R. R. Grummer. 2004. Response of lactating cows to three supplemental fat sources as affected by forage in the diet and stage of lactation: A meta-analysis of literature. Anim. Feed Sci. Technol. 115:65-82.

Orth, R. 1992. Sample day and lactation report. DHIA 200 Fact Sheet A-2. Mid-States DRPC, Ames, IA.
Perfield, J. W., A. L. Lock, J. M. Griinari, A. Saebo, P. Delmonte, D. A. Dwyer, and D. E. Bauman. 2007. Trans-9, cis-11 conjugated linoleic acid reduces milk fat synthesis in lactating dairy cows. J. Dairy Sci. 90:2211-2218.

Peterson, D. G., J. A. Kelsey, and D. E. Bauman. 2002. Analysis of variation in cis-9, trans-11 conjugated linoleic acid (CLA) in milk fat of dairy cows. J. Dairy Sci. 85:2164-2172.

Peterson, D. G., E. A. Matitashvili, and D. E. Bauman. 2003. Dietinduced milk fat depression in dairy cows results in increased trans-10, cis-12 CLA in milk fat and coordinate suppression of mRNA abundance for mammary enzymes involved in milk fat synthesis. J. Nutr. 133:3098-3102.

Petit, H. V. 2010. Review: Feed intake, milk production and milk composition of dairy cows fed flaxseed. Can. J. Anim. Sci. 90:115-127.

Petit, H. V. 2015. Milk production and composition, milk fatty acid profile, and blood composition of dairy cows fed different proportions of whole flaxseed in the first half of lactation. Anim. Feed Sci. Technol. 205:23-30.

Petit, H. V., N. Gagnon, P. Mir, R. Cao, and S. Cui. 2009. Milk concentration of the mammalian lignan enterolactone, milk production, milk fatty acid profile, and digestibility of dairy cows fed diets containing whole flaxseed or flaxseed meal. J. Dairy Res. 76:257-264.

Petit, H. V., M. Ivan, and P. S. Mir. 2005. Effects of flaxseed on protein requirements and $\mathrm{N}$ excretion of dairy cows fed diets with two protein concentrations. J. Dairy Sci. 88:1755-1764.

Porter, L. J. 1986. Number- and weight-average molecular weights for some proanthocyanidin polymers (condensed tannins). Aust. J. Chem. 39:557-562.

Reveneau, C., C. V. D. M. Ribeiro, M. L. Eastridge, and J. L. Firkins. 2012. Interaction of unsaturated fat or coconut oil with monensin in lactating dairy cows fed 12 times daily. II. Fatty acid flow to the omasum and milk fatty acid profile1. J. Dairy Sci. 95:2061-2069. https:// doi.org/10.3168/jds.2011-4888.

Rigout, S., S. Lemosquet, J. E. Van Eys, J. W. Blum, and H. Rulquin. 2002. Duodenal glucose increases glucose fluxes and lactose synthesis in grass silage-fed dairy cows. J. Dairy Sci. 85:595-606.

Schingoethe, D. J., M. J. Brouk, K. D. Lightfield, and R. J. Baer. 1996. Lactational responses of dairy cows fed unsaturated fat from extruded soybeans or sunflower seeds. J. Dairy Sci. 79:1244-1249.

Soita, H. W., J. A. Meier, M. Fehr, P. Yu, D. A. Christensen, J. J. McKinnon, and A. F. Mustafa. 2003. Effects of flaxseed supplementation on milk production, milk fatty acid composition and nutrient utilization by lactating dairy cows. Arch. Tierernahr. 57:107-116.

Sterk, A., B. Vlaeminck, A. M. Vuuren, W. H. Hendriks, and J. Dijkstra. 2012. Effects of feeding different linseed sources on omasal fatty acid flows and fatty acid profiles of plasma and milk fat in lactating dairy cows. J. Dairy Sci. 95:3149-3165.

Urrutia, N., Y. Ying, and K. J. Harvatine. 2017. The effect of conjugated linoleic acid, acetate, and their interaction on adipose tissue lipid metabolism in nonlactating cows. J. Dairy Sci. 100:5058-5067.

Van Soest, P. J., J. B. Robertson, and B. A. Lewis. 1991. Methods for dietary fibre, neutral detergent fibre and non-starch polysaccharides in relation to animal nutrition. J. Dairy Sci. 74:3583-3597.

Vasta, V., D. R. Yáñez-Ruiz, M. Mele, A. Serra, G. Luciano, M. Lanza, L. Biondi, and A. Priolo. 2010. Bacterial and protozoal communities and fatty acid profile in the rumen of sheep fed a diet containing added tannins. Appl. Environ. Microbiol. 76:2549-2555. https://doi .org/10.1128/AEM.02583-09.

Weiss, W. P. 1998. Estimating the available energy content of feeds for dairy cattle. J. Dairy Sci. 81:830-839. 